\title{
New Insights on the Role of Manganese in Alzheimer's Disease and Parkinson's Disease
}

\author{
Airton Cunha Martins Jr. ${ }^{1} \mathbb{D}$, Patricia Morcillo ${ }^{1}$, Omamuyovwi Meashack Ijomone ${ }^{2} \mathbb{D}$, \\ Vivek Venkataramani ${ }^{3}{ }^{\mathbb{D}}$, Fiona Edith Harrison ${ }^{4}$, Eunsook Lee ${ }^{5}$, Aaron Blaine Bowman ${ }^{6}$ and \\ Michael Aschner 1,*iD
}

1 Department of Molecular Pharmacology, Albert Einstein College of Medicine, Bronx, NY 10461, USA; airtoncmjr@gmail.com (A.C.M.J.); patricia.morcillo@einstein.yu.edu (P.M.)

2 Department of Human Anatomy, School of Health and Health Technology, Federal University of Technology Akure, Akure 340252, Nigeria; godmamus@gmail.com

3 Department of Hematology and Medical Oncology and Institute of Pathology, University Medical Center Göttingen (UMG), 37075 Göttingen, Germany; ramani@med.uni-goettingen.de

4 Department of Medicine, Vanderbilt University Medical Center, Nashville, TN 37232, USA; fiona.harrison@Vanderbilt.Edu

5 Department of Pharmaceutical Sciences, Florida A\&M University, Tallahassee, FL 32301, USA; eunsook.lee@famu.edu

6 School of Health Sciences, Purdue University, West Lafayette, IN 47907-2051, USA; bowma117@purdue.edu

* Correspondence: michael.aschner@einstein.yu.edu; Tel.: +1-718-430-2317

Received: 9 August 2019; Accepted: 20 September 2019; Published: 22 September 2019

\begin{abstract}
Manganese (Mn) is an essential trace element that is naturally found in the environment and is necessary as a cofactor for many enzymes and is important in several physiological processes that support development, growth, and neuronal function. However, overexposure to Mn may induce neurotoxicity and may contribute to the development of Alzheimer's disease (AD) and Parkinson's disease (PD). The present review aims to provide new insights into the involvement of $\mathrm{Mn}$ in the etiology of AD and PD. Here, we discuss the critical role of Mn in the etiology of these disorders and provide a summary of the proposed mechanisms underlying Mn-induced neurodegeneration. In addition, we review some new therapy options for AD and PD related to Mn overload.
\end{abstract}

Keywords: manganese; Alzheimer's disease; Parkinson's disease; neurodegeneration

\section{Introduction}

Transition metals such as manganese $(\mathrm{Mn})$, iron (Fe), cobalt (Co), and zinc (Zn) are essential for all life forms as at least $40 \%$ of enzymes require a metal as a constituent of many metalloenzymes serving as an enzyme activator [1,2]. As a naturally occurring mineral, Mn is one of the most abundant metals in the tissues of mammals and has been shown to function in many key biological processes, serving as a catalyst, enzyme cofactor, and gene modulator. Mn is required for a variety of physiological processes including brain and skeletal development, blood clotting, reproduction, neuronal function, antioxidant defense, maintaining immune integrity, and is, as recently revealed, also critically involved in anti-viral innate immunity [3-5]. Mn is found in soil, water, and food legumes and has 11 oxidation states, but it is predominantly in biological tissues as $\mathrm{Mn}^{2+}$ and $\mathrm{Mn}^{3+}[6,7]$. Mn deficiency has been associated with increased susceptibility to seizures, birth, and skeletal defects [7-9].

Normal Mn concentration varies depending on the biological tissues evaluated. Generally, the estimated value of $\mathrm{Mn}$ in the body is about $4-12 \mu \mathrm{g} / \mathrm{L}$ in whole blood, $1-8 \mu \mathrm{g} / \mathrm{L}$ in urine, and $0.4-0.85 \mu \mathrm{g} / \mathrm{L}$ in serum $[10,11]$. Industrial sources of exposure are a major public health challenge. The inhalation of Mn particulates may occur during occupational activities (such as mining and welding) 
or the use of Mn containing materials during production [12-15]. Another pathway of exposure is the use of total parenteral nutrition (TPN) to manage health conditions such as gastrointestinal tract and liver damage [16]. Individuals receiving long-term TPN are at risk of suffering from extrapyramidal motor dysfunction associated with $\mathrm{Mn}$ accumulation in various brain regions [17]. Moreover, experimental investigations with a Mn enhanced diet in developing rats have demonstrated increased Mn accumulation in certain brain regions and alterations in brain neurotransmitters [18].

A multitude of neurodegenerative disorders such as Parkinson's disease (PD), Alzheimer's disease (AD), Huntington's disease (HD), and amyotrophic lateral sclerosis (ALS) are characterized by metal dyshomeostasis, which may also contribute to the disease-specific protein aggregations $[19,20]$.

Studies are beginning to show links between brain Mn concentration and the development of AD or AD-like symptoms, although the data are mixed as to the nature of the relationship. Tong et al. [21] showed increases in plasma A $\beta$ peptides (one of the two key proteins implicated in AD) associated with an increased concentration of Mn. This was presumed to indicate a greater $A \beta$ burden in the brain. In $\mathrm{AD}$, the $\mathrm{A} \beta$ peptide is proteolytically cleaved from the larger amyloid precursor protein (APP) at a higher rate than normal. In contrast, exposure of neuroblastoma cell line SH-SY5Y cells to Mn led to decreased viability and lower expression of APP, which could also limit non-amyloidic cleavage to protective $\operatorname{SAPP} \alpha[22,23]$. Mn exposure also altered the ratio between the $\mathrm{Fe}^{2+}$ and $\mathrm{Fe}^{3+}$ driving oxidative environment, which may also drive APP toward amyloidogenic cleavage in the human brain, although this was not tested directly $[23,24]$. However, a meta-analysis of 17 studies showed an association between decreased serum Mn levels of $\mathrm{AD}$ and patients with mild cognitive impairment (MCI), suggesting a potentially contributory role for Mn deficiency in disease development [25].

Excess accumulation of $\mathrm{Mn}$ is called manganism. This disorder has phenotypic features analogous to idiopathic PD with some distinct differences [26]. Mn-induced parkinsonism has been shown to affect dopaminergic neurons as well as other monoaminergic neurotransmitters $[3,27]$ predominantly in the basal ganglia (including striatum, globus pallidus, and substantia nigra) and limbic structures [28,29]. Table 1 summarizes the main findings in PD, parkinsonism and AD regarding the motor and non-motor symptoms, affected areas, pathologic phenotype, and pathophysiological mechanisms.

Table 1. An overview of the different findings in PD, parkinsonism, and AD.

\begin{tabular}{|c|c|c|c|}
\hline Parameter & Parkinson Disease & Parkinsonism & Alzheimer's Disease \\
\hline Motor symptoms & $\begin{array}{ll}- & \text { Rigidity } \\
- & \text { Bradykinesia } \\
- & \text { Resting tremors }\end{array}$ & $\begin{array}{ll}- & \text { Rigidity } \\
- & \text { Bradykinesia } \\
- & \text { Steppage gait } \\
- & \text { Less tremors } \\
- & \text { Painful limb spasms } \\
- & \text { Dystonia }\end{array}$ & $\begin{array}{ll}- & \text { Not common } \\
- & \text { Eventually walking difficult } \\
- & \text { Swallowing difficulties }\end{array}$ \\
\hline Non motor symptoms & $\begin{array}{ll}- & \text { Depression } \\
- & \text { REM sleep behavior disorders }\end{array}$ & $\begin{array}{ll}- & \text { Dementia } \\
- & \text { Hallucinations } \\
- & \text { Memory loss } \\
- & \text { Disorientation } \\
- & \text { Illusions/Delusions }\end{array}$ & $\begin{array}{ll}- & \text { Cognitive impairment } \\
- & \text { Dementia } \\
- & \text { Memory loss }\end{array}$ \\
\hline Affected areas & $\begin{array}{l}\text { - Substantia nigra, critical for } \\
\text { dopamine synthesis }\end{array}$ & $\begin{array}{l}\text { - Mainly in basal ganglia, } \\
\text { - Cerebellum, red nucleus, cortex, } \\
\text { thalamus and anterior horn of } \\
\text { the spinal cord }\end{array}$ & $\begin{array}{l}\text { Loss of neurons in the cortex } \\
\text { and hippocampus }\end{array}$ \\
\hline Pathologic phenotype & $\begin{array}{ll}- & \begin{array}{l}\text { Dopaminergic } \\
\text { neurons degeneration }\end{array} \\
- & \text { Lewy bodies } \\
- & \text { Therapeutic response } \\
\text { to levodopa }\end{array}$ & $\begin{array}{ll}\text { - } & \begin{array}{l}\text { Nigrostriatal } \\
\text { dopaminergic dysfunction }\end{array} \\
\text { - } & \text { Absence response to levodopa } \\
\text { - } & \text { Failure to detect } \\
\text { fluorodopa uptake }\end{array}$ & $\begin{array}{ll}- & \text { Neurofibrillary tau tangles } \\
- & \text { Amyloid } A \beta \text { plaques } \\
- & \text { cell loss } \\
- & \text { brain shrinkage }\end{array}$ \\
\hline Pathophysiological mechanisms & \multicolumn{2}{|c|}{$\begin{array}{l}\text { Oxidative stress, protein aggregation, impaired proteasomal and autophagy } \\
\text { functions, excitotoxicity, aberrant signal transduction, mitochondrial } \\
\text { dysfunction and cell death pathways. }\end{array}$} & $\begin{array}{l}\text { Oxidative stress, mitochondrial } \\
\text { dysfunction, decrease in } \\
\text { cholinergic } \\
\text { innervation, neuroinflammation }\end{array}$ \\
\hline
\end{tabular}


Given the above, this review addresses the involvement of $\mathrm{Mn}$ in cellular and molecular mechanisms that cause neurodegeneration and the accompanying symptoms inherent to AD and PD.

\section{Oxidative Stress and Mitochondrial Dysfunction}

Oxidative stress plays important roles in neurodegenerative disorders such as PD and AD and its progression through an imbalance between reactive oxygen and nitrogen species production and neutralization by endogenous antioxidant defense mechanisms [30]. Due to the high metabolic activity of neurons consuming at least $20 \%$ of the total oxygen and calories, the brain is highly vulnerable to oxidative injury $[31,32]$. The generation of unstable molecules such as superoxide radical $\left(\mathrm{O}_{2}{ }^{\bullet-}\right)$, hydrogen peroxide $\left(\mathrm{H}_{2} \mathrm{O}_{2}\right)$, and hydroxyl radical $\left({ }^{\bullet} \mathrm{OH}\right)$ that can interact with biological macromolecules, leads to structural changes and damage in lipids, proteins, and nucleic acids.

Studies have shown that $\mathrm{Mn}$ is involved in significant changes in the level of activity of the antioxidant enzymes including isoforms of superoxide dismutase (SOD), catalase (CAT), and glutathione peroxidase (GPx) [33,34]. Furthermore, Mn contributes to oxidative stress by increasing production of nitric oxide through the activation of the inducible nitric oxide synthase in astrocytes [35]. Indeed, astrocytes have been linked to neurotoxic effects by the activation of proinflammatory responses [36]. In this regard, earlier studies have reported that after Mn exposure, NF- $\mathrm{KB}$ in astrocytes may stimulate the production of inflammatory cytokines and chemokines (including IL-6, TNF, CCL2, and CCL5) [37-39] Moreover, it have been demonstrated that Mn exposure increases mRNA expression of pro-inflammatory cytokines, IL-1b, TNF- $\alpha$, and COX-2. These studies suggest that the astrocytic NF-kB pathway may have a critical role in inflammatory signaling processes in neurodegenerative diseases induced by Mn [38,40]. On the other hand, excessive Mn exposure can directly evoke free radical formation due to the redox-active nature of this transition metal, resulting in direct oxidation of membrane lipids, DNA, amino acids, neurotransmitters, and other relevant biomolecules [41]. Regarding neurodegenerative diseases, Balmus et al. [42] recently demonstrated that high Mn levels in AD patients were strongly positively correlated with low antioxidant defenses, measured as decreased GPx activity, and increased lipid peroxidation measured as enhanced malondialdehyde (MDA), secondary to excessive ROS production. In addition, alternative and complementary animal models used in the study of PD such as Caenorhabditis elegans and Drosophila melanogaster have confirmed a relationship between Mn exposure and changes in oxidative parameters such as decreased glutathione levels, enhanced MDA (that measure of lipid peroxidation) as well as levels of protein carbonyls (a measure of protein oxidation) [43].

Mechanistically, it has been proposed that Mn-induced oxidative stress in neurodegenerative diseases might be secondary to excessive iron ( $\mathrm{Fe}$ ) accumulation. Mn has been shown to block protein translation of APP, which is responsible for the stabilization of the membrane-bound $\mathrm{Fe}^{2+}$-exporter ferroportin and heavy-chain Ferritin (H-Ferritin). These proteins sequester $\mathrm{Fe}^{2+}$ via conversion to redox inactive $\mathrm{Fe}^{3+}$ by increasing the binding of iron regulatory protein-1(IRP1) to the iron responsive element (IRE) on the $5^{\prime}$-UTR of APP and H-Ferritin mRNA $[23,44]$. This is important since $\mathrm{Fe}^{2+}$ is a major intrinsic generator of ROS, responsible for the decomposition of $\mathrm{H}_{2} \mathrm{O}_{2}$, and in turn, producing $\mathrm{OH}$ hydroxyl group by the Fenton reaction and Haber-Weiss, thereby contributing to Mn-induced oxidative stress [45,46].

Mn-induced oxidative stress in neurodegenerative diseases can also be secondary to a mitochondrial dysfunction, which plays a central role in PD and AD [47-49]. $\mathrm{Mn}^{2+}$ interferes with $\mathrm{Ca}^{2+}$ homeostasis within the mitochondria by occupying $\mathrm{Ca}^{2+}$ binding sites [50,51], triggering an increase in mitochondrial $\mathrm{Ca}^{2+}$ levels, which interfere with oxidative respiration and induce oxidative stress [52]. The ROS generated by excessive Mn levels promote the opening of the mitochondrial permeability transition pore, causing a loss of membrane potential and impairing ATP synthesis and mitochondrial swelling, thereby contributing to cellular apoptosis [53,54]). Moreover, Mn may directly affect mitochondrial homeostasis by inhibiting the electron transport chain, leading to decreased ATP formation, increased leakage of electrons, and enhanced $\mathrm{O}_{2}{ }^{--}$generation [55]. Indeed, Mn inhibits 
electron transport chain in two independent sites in brain mitochondria: while the primary site is electron transport chain complex II [56-58], the inhibition of complex I activity in isolated rat brain mitochondria has also been reported $[50,59]$ or in mesencephalic DA neurons derived from human induced pluripotent stem cells (hiPSC) [60].

Taken together, these findings suggest that Mn promotes neurotoxicity associated with AD and PD by fueling ROS production, causing cellular oxidative stress and perturbing the mitochondrial electron transport chain impairing mitochondrial enzyme activity and mitochondrial membrane potential affecting ATP-dependent energy production.

\section{Mn-Mediated Regulation of Amyloid Precursor Protein (APP) and Amyloid- $\beta$ (A $\beta$ ) Aggregation}

Aside from aggregates of the hyperphosphorylated tau protein building neurofibrillary tangles, the formation and deposition of $A \beta$ plaques is a cardinal feature of $A D$ pathogenesis [61]. A $\beta$ plaques are produced by sequential cleavage of APP via $\alpha_{-}, \beta_{-}$, and $\gamma$-secretase enzymes to produce APP fragments including A $\beta$ and c-terminal fragments. The majority of APP cleavage is via $\alpha$-secretase, which cleaves APP between amino acids 612 and 613 and produces soluble APP $\alpha$, which possesses neuroprotective features. In contrast, amyloidogenic cleavage occurs when APP is cleaved by $\beta$ and $\gamma$-secretases generating $A \beta$ monomers. These monomers aggregate to generate oligomers and fibrils, which are considered to be neurotoxic. Ultimately, continued aggregation of $A \beta$ peptides into $\beta$-sheets generates the hallmark senile plaques $[62,63]$. A recent study showed the binding of $\mathrm{Mn}$ to the monomeric $A \beta$ peptide in vitro, without any major effects on $A \beta$ aggregation and no obvious effects on plaque formation. These data suggest weak and transient interactions in this binding, since aggregation kinetics and fibril morphology of $A \beta$ do not change according to the presence or absence of Mn when monitored by spectroscopy and fluorescence experiments [64]. Moreover, other metals such as copper $(\mathrm{Cu})$ and zinc $(\mathrm{Zn})$ found in the human brain have higher interaction with $\mathrm{A} \beta$ aggregation than $\mathrm{Mn}[65,66]$. Therefore, additional studies are required to better understand the effects of $\mathrm{Mn} / \mathrm{A} \beta$ interactions on $\mathrm{A} \beta$ aggregation and the molecular mechanisms involved [64,67].

Altered serum Mn level between AD and control populations has been observed in multiple studies. However, methodological limitations and a lack of consistency between study approaches have failed to accurately elucidate the role of Mn in AD [21,25,68-70]. High pollution in Mexico City led to selective accumulation of $\mathrm{Mn}$ (and not iron (Fe)) in brains, whereas the same changes were not observed in lung [71]. Mn accumulation in young adults was associated with diffuse A $\beta$ plaques (in 51\%) and hyperphosphorylated tau (in 40\%), suggesting a direct impact on development of AD [72]. Similar pollution exposure led to increased expression of nuclear neuronal NF- $\mathrm{KB}$ and iNOS, altered blood-brain barrier (BBB) function, and diffuse $\mathrm{A} \beta$ plaques and neurofibrillary tangles in dogs $[73,74]$. Dogs represent a good model of pathological aging because they exhibit many of the same pathological signs of $A D$ including $A \beta$ accumulation and deposition. Intravenous $\mathrm{Mn}(3.3-5.0 \mathrm{mg} / \mathrm{kg})$ in Cynomologous Macaques increased brain $\mathrm{Mn}$ independent of changes in $\mathrm{Fe}$, upregulated expression of amyloid- $\beta$-like protein 1 mRNA (APLP1, a member of the amyloid precursor protein family), and led to diffuse $A \beta$ plaques and degenerating cells $[75,76]$. These pathological signs were not observed in the control brains. Moreover, these Mn-treated groups showed impaired spatial working memory and fine motor skills, and increased compulsive like behaviors [76] each of which are associated with degenerative diseases and dementia. MnSOD expression in hippocampus was 3- to 11-fold greater in hippocampal regions CA1-CA3 in AD patients than the controls [77] tying differences in Mn handling to areas of the brain expressing high pathological change, and further supporting a direct relationship between an Mn-dependent antioxidant enzyme and A $\beta$. A similar neuropathology reported in canines, non-human primates, and humans strongly suggests a shared underlying pathway that is conserved across species. 


\section{Aggregation of $\alpha$-Synuclein in Mn-Induced Neurotoxicity}

Alpha-synuclein $(\alpha \operatorname{Syn})$ is a chaperon protein with 140 amino acids widely expressed in neural tissue where it predominantly localizes to the presynaptic terminal. It can play important roles in the regulation of synaptic plasticity, vesicle transport, and dopaminergic neurotransmission [78]. $\alpha$ Syn is a protein with a natural tendency to aggregate into oligomers and is a key player in the pathology of PD $[79,80]$. In the same way, although nuclear magnetic resonance (NMR) studies have shown that $\alpha$ Syn has a poor affinity for $\mathrm{Mn}^{2+}$ in its C-terminal binding site, $\mathrm{Mn}^{2+}$ can trigger misfolding and accumulation of $\alpha$ Syn protein [81,82]. Indeed, emerging evidence indicates that $\alpha$ Syn oligomerization is a major culprit for Mn-induced neurotoxicity [83-85]. Further evidence that Mn regulates exosome-mediated extracellular micro RNA (miRNAs) comes from the MN9D dopaminergic cell culture model [86]. Mn exposure significantly upregulated the release of exosomes from cells to the extracellular environment in wild-type human $\alpha$ Syn-expressing MN9D dopaminergic cells. Moreover, Mn-induced exosomes contain miRNAs, which are involved in the regulation of key biological pathways including protein aggregation, autophagy, inflammation, and neurodegenerative disease [87,88]. Harischandra et al. [89] demonstrated that Mn also promotes the aggregation and prion-like exosomal transmission of $\alpha$ Syn from cell to cell, resulting in dopaminergic neurotoxicity in a mouse model of $\mathrm{Mn}^{2+}$ exposure. Together, these results indicate that $\mathrm{Mn}^{2+}$ exposure promotes $\alpha$ Syn secretion in exosomal vesicles, which subsequently evokes proinflammatory and neurodegenerative responses in both cell culture and animal models.

Mn exposure may induce neurotoxicity by the overexpression of $\alpha$ Syn, leading to enhanced $\alpha$ Syn levels and resulting in $\alpha$ Syn aggregation and misfolding [84,90]. Indeed, $\alpha$ Syn oligomerization might be the major factor responsible for Mn-induced autophagy dysregulation and neuronal injury [91]. Such a role is plausible given the requirement for autophagic degradation of $\alpha$ Syn monomers or oligomers [92] and the role of dysregulated autophagy in the development of neurodegenerative disorders [93]. In $\alpha$-Syn knockout mice $\left(\alpha-\mathrm{Syn}^{-/-}\right)$excessive autophagy and aggravation of apoptosis following Mn exposure compared to control mice has recently been shown [91]. These results support the potential neuroprotective role of $\alpha$ Syn in ameliorating Mn-induced excessive autophagy and neuronal injury.

\section{Mn-Mediated Effects on the Cholinergic System}

The cholinergic system encompasses the neurotransmitter acetylecholine (ACh), that is synthesized from choline and acetyl-coenzyme A, mediated by choline acetyltransferese (ChaT) and stored in the presynaptic vesicles. Once released into the synaptic cleft, ACh binds to pre- and postsynaptic muscarinic and nicotinic receptors and is hydrolyzed by the enzymes cholinesterases (acetylcholinesterase (AChE) and butyrylcholinesterase (BuChE)). The cholinergic system plays an important role in cognitive domains involved in learning, attention, and memory [94,95]. In fact, impairments in the cholinergic system are associated with several illness such as myasthenia gravis and $\mathrm{AD}$ [96]. In AD patients, loss of neurons in the basal forebrain leads to dramatic changes in cholinergic innervation in the cortex and the hippocampus. This cell loss is correlated with memory and attention deficits [97-99]. Presynaptic cholinergic dysfunctions, over-activation of acetylcholinesterase (AChE), decrease in levels of ACh followed by dysfunction and eventual death of cholinergic neurons, support the cholinergic hypothesis of the disease [97].

Several studies have shown that Mn perturbs the cholinergic system, leading to locomotor, emotional, behavioral, and cognitive dysfunction. Mn can modify the activity of enzymes involved in cholinergic transmission such as AChE [100,101]. Rats treated with Mn in drinking water for 30 days showed significant increase in $\mathrm{AChE}$ activity as well as enhanced $\mathrm{AChE}$ expression in the cerebellum [100]. Similarly, short-term administration of $\mathrm{MnCl}_{2}$ enhanced AChE activity in rat brains [102]. Moreover, in a study with rats treated with a Mn enriched diet, brain extracts showed increased AChE activity compared to the control group [101]. In contrast, long-term treatment of rats with $\mathrm{Mn}$ in drinking water (approximately $40 \mathrm{mg} \mathrm{Mn} / \mathrm{kg}$-day) for over two years resulted in significant 
decreases of AChE activity in the hypothalamus, cerebellum, and striatum $[103,104]$. These conflicting results after Mn exposure on AChE activity suggest that the effects of Mn may depend on age, dose, route of exposure, frequency, and duration [81,101,105].

Mn-induced inhibition of AChE activity in the rat brain increased F2-isoprostanes levels in a dose-dependent manner, suggesting that $\mathrm{Mn}$ promotes changes in neuronal oxidative stress and neuroinflammatory biomarkers, possibly due to the inhibition of AChE [106,107]. Mn exposure via intranasal administration resulted in increased oxidative stress and reduced nicotinic acetylcholine receptor levels in the prefrontal cortex, suggesting that Mn contributes to cholinergic neurotransmission disruption in the brain areas critical for cognition [108]. Mn also induced cholinergic neurodegeneration in C. elegans including upregulation of mRNA of ace-2, an enzyme responsible for hydrolyzing ACh into acetate and choline. These changes suggest upregulation of cholinergic degradation enzyme, which can lead to impaired behavioral parameters such as pharyngeal pumping and body bends for analysis of locomotion [109]. In agreement with these findings, studies in vitro reported increased AChE activity in cultured cells due to oxidative stress [110]. Moreover, studies suggested that AChE activity has been demonstrated to increase $A \beta$ formation within and around amyloid plaques and makes clear the involvement of this system in the pathogenic development of AD by influencing the process that leads to amyloid toxicity [111]. Given the role of $\mathrm{Mn}$ in mediating cholinergic function, and the links between cholinergic changes including $\mathrm{AChE}$ activity, $\mathrm{A} \beta$ generation and aggregation, and oxidative damage in $\mathrm{AD}$, it is clear that there is a strong potential role for $\mathrm{Mn}$ in $\mathrm{AD}$ disease development.

\section{Mn-Induced Parkinsonism and the Involvement of the Dopaminergic System}

The neurotransmitter system that has received the most attention in the study of Mn neurotoxicity is the dopaminergic (DAergic) system. The neurobiological basis for the effect of Mn on dopamine metabolism, neurotransmission, and selective accumulation of $\mathrm{Mn}$ in the basal ganglia following overexposure has yet to be fully delineated [7]. Several studies have shown that the divalent metal transporter 1 (DMT1), an important transporter of Mn (and other divalent ions) in the brain, is highly expressed in the basal ganglia. DMT1 upregulation has been posited to be associated with oxidative stress and dopaminergic cell loss, suggesting this transporter may contribute to neurodegeneration [112-114]. Moreover, it is clear that Mn overexposure induces DAergic neurodegeneration [115-118]. This result is supported by neuroimaging modalities such as positron emission tomography (PET), single-photon emission computed tomography (SPECT), and magnetic resonance imaging (MRI) [7,119]. In PD, both PET and SPECT imaging showed altered dopamine neuron function and terminal density in key pathological areas such as the dorsal striatum, but preserved or even increased postsynaptic D2 dopamine receptor raclopride binding (D2R) [120,121]. In contrast, Mn-exposed workers, nonhuman primates, or rodents, revealed normal flurodopa uptake and dopamine transporter (DAT) density, decreased dopamine release, and D2R in the striatum [14,118], and no decrease in the numbers of substantia nigra pars compacta neurons [116,122]. A recent report in non-human primates provides evidence of Mn-induced alterations in PET imaging of the frontal cortex DAR and D1-dopamine receptor (D1R) that may be associated with working memory and attention deficits observed in Mn-exposed subjects [123]. Conversely, using a new technique called nondisplaceable binding potential (NMB) PET, nigral D2R increased in workers and welders with Mn exposure and clinical parkinsonism, indicating dose-dependent dopaminergic dysfunction of the SN secondary to Mn exposure [124]. Increases in striatal D2R binding may represent compensatory upregulation of striatal D2Rs in early stages of PD, referred to as D2R denervation supersensitivity [125]. However, with progressive degeneration of nigrostriatal pathways, striatal D2R binding decreased to normal or reduced levels when compared to healthy controls $[126,127]$.

Studies using cell cultures consistently demonstrate that DA neurons are susceptible to Mn exposure [128-130], however, the exact cellular and molecular mechanisms of Mn-induced neurotoxicity remain elusive. $\mathrm{Mn}$-induced neurotoxicity in dopaminergic neurons has been studied, and several key players such as protein kinase C delta (PKCd) (131) and caspase 3 signaling have been identified [131, 
132]. Furthermore, Mn exposure induces mitochondria-mediated apoptosis in neurons, which is partially facilitated by p53 [133], and DNp73 antagonizes the functional p53 by regulating the expression of anti-apoptotic molecules such as Bcl-xL and Mcl-1 [134]. In addition, p73 gene expression resulting in enhanced susceptibility to apoptotic cell death in N27 dopaminergic neuronal mode [135]. c-RET has been reported to be associated with the dopamine-producing pathway through enhancing the transcription of tyrosine hydroxylase (TH), which is a rate-limiting enzyme in dopamine biosynthesis [136]. TH has been used as one of the indicators to determine the level of dopamine production [137].

\section{Mn-Mediated Effects on the GABAergic System}

Excessive exposure to $\mathrm{Mn}$ can cause a variety of effects not only in the striatum, but also in the globus pallidus [138] as well as abnormalities in GABAergic transmission [139]. Indeed, Mn accumulates in the basal ganglia, particularly in the globus pallidus [140]. GABA plays a key role in mediating the direct and indirect pathway of the basal ganglia, both of which have GABAergic projections to the thalamus [141]. The basal ganglia-thalamocortical pathway is mainly involved in the regulation of motor coordination [142]. In this context, studies have evaluated the effects of Mn on GABA and controversial results have been found [7]. Studies on non-human primates have shown no change in brain GABA concentration under Mn exposure [27,143]. In contrast, recent investigations using magnetic resonance spectroscopy have found elevated thalamic GABA levels in lower-exposure occupational setting [144,145] and PD patients [146]. In addition, Ma et al. [138] have shown with edited magnetic resonance spectroscopy and MRI an increase of thalamic GABA levels in a group of welders with higher exposure to $\mathrm{Mn}$ as well as poorer performance in general motor function. However, welders with lower Mn exposure did not differ from the controls in GABA levels or motor performance. Furthermore, in welders, the thalamic GABA levels were best predicted by past-12-months of Mn exposure levels and were influenced by the Mn deposition in the substantia nigra and globus pallidus. Importantly, both thalamic GABA levels and motor function displayed a non-linear pattern of response to Mn exposure, suggesting a threshold effect. These data suggest that the effects of Mn on the GABAergic system are complex. However, results on striatal GABA concentrations in PD are controversial [146,147]. Accordingly, Casjens et al. [148] did not provide evidence that striatal and thalamic GABA differ between Mn-exposed workers, PD patients, and controls. Differences in species, length of exposure duration, and the challenge to detect small changes in GABA could all play a role in the effect of Mn neurotoxicity. Therefore, more research is necessary to establish the effect of Mn exposure on GABA neurotransmission.

\section{New Therapies to Treat Mn-Induced Parkinsonism and AD}

Although different therapeutic approaches have been studied in Mn-induced neurotoxicity [7,81], there is currently no protective strategy against Mn neurotoxicity. Originally, patients with Mn-induced parkinsonism were treated with levodopa, but were unresponsive to the treatment, possibly due to the relatively intact nigrostriatal pathway in the latter phase of the disorder [149,150]. More recently, mitochondria have been highlighted as a therapeutic target against Mn neurotoxicity. In animal models, the amino acid taurine has been investigated as a potential treatment for manganism. In mice, taurine alleviated Mn-induced locomotor deficits, mitigated oxidative stress biomarkers, and preserved indices of mitochondrial functionality in brain tissue [151]. Additionally, taurine administration preserved mitochondrial ATP, prevented mitochondrial depolarization and swelling, and increased mitochondrial dehydrogenases activity [152]. Interestingly, it has also been found that Mn neurotoxicity is associated with disturbances in taurine homeostasis [153]. Furthermore, co-administration of taurine improves the spatial learning and memory ability impaired by sub-chronic Mn exposure [154]. Other treatment options include rasagiline, a monoamine oxidase inhibitor that inhibits the metabolism of striatal dopamine used in the clinic for PD. Ragasaline provided a small, but significant protection against the 
initial Mn-induced reactive oxygen/nitrogen species (RONS) formation as measured in iPSC- derived human dopamine neurons [60].

Recently, the use of bioinformatic methods has been trialed to predict the possible molecular mechanisms underlying Mn-induced $\mathrm{AD}$ and screen possible molecules to reverse the neurotoxicity or AD development. Using the connectivity map (CMAP) tool, it was demonstrated that Tyrphostin AG-825, an inhibitor of tyrosine phosphorylation, could be a potential agent for overcoming Mn-induced neurotoxicity or AD development [155]. This molecule is specifically inhibiting ErbB2 (a member of the epidermal growth factor receptor (EGFR)/ErbB family) that plays an important role in the pathogenesis of $\mathrm{AD}$ and is strongly associated with neuritic plaques in AD [156], suggesting that this molecule could be used in future studies to reverse the biological process related with neurotoxicity induced by metal.

\section{Conclusions}

Although Mn has an important role in physiological functions, especially in the brain, overexposure to this metal leads to toxic effects. Studies have shown that oxidative stress and the imbalance in mitochondrial energy metabolism are involved in Mn neurotoxicity, which induces or mediates AD and PD. Moreover, neurotransmitter systems such as the cholinergic system, dopaminergic system, and GABA system might be affected by $\mathrm{Mn}$, suggesting the involvement of these neurotransmitter systems in these neurological diseases. Overall, the findings summarized in this review warrant further investigation into the molecular mechanisms and pathophysiological interrelationship between $\mathrm{Mn}$ exposure and neurodegenerative disorders such as AD and PD.

Moreover, new approaches to validate novel biomarkers and create better disease models to AD and PD induced by Mn as well as proteomic and transcriptomic analysis alongside novel bioinformatic tools are essential for advancing knowledge of the disease mechanisms induced by Mn. Furthermore, studies to investigate potential molecular targets and new therapeutic strategies for these devastating illnesses are urgently required.

Author Contributions: A.C.M.J. had the original idea for the review, conducted the literature survey, and provided conceptual input. P.M. and O.M.I., conducted the literature survey. A.B.B., F.E.H., and V.V. contributed to the literature search and edited the manuscript. M.A. and E.L. reviewed the manuscript. All authors contributed to writing the manuscript.

Funding: This research was funded by National Institutes of Health [NIH] and Veterans Affairs [VA] grants: NIH/NIEHS RO1 ES010563 [ABB and MA], NIH/NIEHS R01 ES024756 [EL], NIH/NIEHS RO1 ES016931-12S1 [ABB, FEH, MA], and I01 CX001610-01 [FEH].

Conflicts of Interest: The authors declare no conflicts of interest.

\section{References}

1. Hood, M.I.; Skaar, E.P. Nutritional immunity: Transition metals at the pathogen-host interface. Nat. Rev. Microbiol. 2012, 10, 525. [CrossRef] [PubMed]

2. Andreini, C.; Bertini, I.; Cavallaro, G.; Holliday, G.L.; Thornton, J.M. Metal ions in biological catalysis: From enzyme databases to general principles. J. Biol. Inorg. Chem. 2008, 13, 1205-1218. [CrossRef] [PubMed]

3. Fitsanakis, V.A.; Au, C.; Erikson, K.M.; Aschner, M. The effects of manganese on glutamate, dopamine and gamma-aminobutyric acid regulation. Neurochem. Int. 2006, 48, 426-433. [CrossRef] [PubMed]

4. Chen, Y.; Shen, Y.; Wang, W.; Wei, D. $\mathrm{Mn}^{2+}$ modulates the expression of cellulase genes in Trichoderma reesei Rut-C30 via calcium signaling. Biotechnol. Biofuels 2018, 11, 54. [CrossRef] [PubMed]

5. Wang, C.; Guan, Y.; Lv, M.; Zhang, R.; Guo, Z.; Wei, X.; Du, X.; Yang, J.; Li, T.; Wan, Y.; et al. Manganese Increases the Sensitivity of the cGAS-STING Pathway for Double-Stranded DNA and Is Required for the Host Defense against DNA Viruses. Immunity 2018, 48, 675-687. [CrossRef] [PubMed]

6. Chen, P.; Chakraborty, S.; Mukhopadhyay, S.; Lee, E.; Paoliello, M.M.; Bowman, A.B.; Aschner, M. Manganese homeostasis in the nervous system. J. Neurochem. 2015, 134, 601-610. [CrossRef] [PubMed]

7. Kwakye, G.F.; Paoliello, M.M.; Mukhopadhyay, S.; Bowman, A.B.; Aschner, M. Manganese-Induced Parkinsonism and Parkinson's Disease: Shared and Distinguishable Features. Int. J. Environ. Res. Public Health 2015, 12, 7519-7540. [CrossRef] 
8. Gonzalez-Reyes, R.E.; Gutierrez-Alvarez, A.M.; Moreno, C.B. Manganese and epilepsy: A systematic review of the literature. Brain Res. Rev. 2007, 53, 332-336. [CrossRef]

9. Zhaojun, W.; Lin, W.; Zhenyong, W.; Jian, W.; Ran, L. Effects of manganese deficiency on serum hormones and biochemical markers of bone metabolism in chicks. J. Bone Miner Metab. 2013, 31, 285-292. [CrossRef]

10. Da Silva, A.L.C.; Urbano, M.R.; Almeida Lopes, A.C.B.; Carvalho, M.F.H.; Buzzo, M.L.; Peixe, T.S.; Aschner, M.; Mesas, A.E.; Paoliello, M.M.B. Blood manganese levels and associated factors in a population-based study in Southern Brazil. J. Toxicol. Environ. Health A 2017, 80, 1064-1077. [CrossRef]

11. O'Neal, S.L.; Zheng, W. Manganese Toxicity Upon Overexposure: A Decade in Review. Curr. Environ. Health Rep. 2015, 2, 315-328. [CrossRef] [PubMed]

12. Bowler, R.M.; Koller, W.; Schulz, P.E. Parkinsonism due to manganism in a welder: Neurological and neuropsychological sequelae. Neurotoxicology 2006, 27, 327-332. [CrossRef] [PubMed]

13. Aschner, M.; Guilarte, T.R.; Schneider, J.S.; Zheng, W. Manganese: Recent advances in understanding its transport and neurotoxicity. Toxicol. Appl. Pharmacol. 2007, 221, 131-147. [CrossRef] [PubMed]

14. Huang, C.C. Parkinsonism induced by chronic manganese intoxication-An experience in Taiwan. Chang Gung Med. J. 2007, 30, 385-395. [PubMed]

15. Cowan, D.M.; Fan, Q.; Zou, Y.; Shi, X.; Chen, J.; Aschner, M.; Rosenthal, F.S.; Zheng, W. Manganese exposure among smelting workers: Blood manganese-iron ratio as a novel tool for manganese exposure assessment. Biomarkers 2009, 14, 3-16. [CrossRef]

16. Aschner, J.L.; Aschner, M. Nutritional aspects of manganese homeostasis. Mol. Aspects Med. 2005, 26, 353-362. [CrossRef] [PubMed]

17. Peres, T.V.; Pedro, D.Z.; de Cordova, F.M.; Lopes, M.W.; Goncalves, F.M.; Mendes-de-Aguiar, C.B.N.; Walz, R.; Farina, M.; Aschner, M.; Leal, R.B. In Vitro Manganese Exposure Disrupts MAPK Signaling Pathways in Striatal and Hippocampal Slices from Immature Rats. Biomed Res. Int. 2013, 2013, 769295. [CrossRef]

18. Garcia, S.J.; Gellein, K.; Syversen, T.; Aschner, M. A manganese-enhanced diet alters brain metals and transporters in the developing rat. Toxicol. Sci. 2006, 92, 516-525. [CrossRef]

19. Brown, D.R. Brain proteins that mind metals: A neurodegenerative perspective. Dalton Trans. 2009, 4069-4076. [CrossRef]

20. Williams, B.B.; Kwakye, G.F.; Wegrzynowicz, M.; Li, D.; Aschner, M.; Erikson, K.M.; Bowman, A.B. Altered manganese homeostasis and manganese toxicity in a Huntington's disease striatal cell model are not explained by defects in the iron transport system. Toxicol. Sci. 2010, 117, 169-179. [CrossRef]

21. Tong, Y.; Yang, H.; Tian, X.; Wang, H.; Zhou, T.; Zhang, S.; Yu, J.; Zhang, T.; Fan, D.; Guo, X.; et al. High manganese, a risk for Alzheimer's disease: High manganese induces amyloid-beta related cognitive impairment. J. Alzheimers Dis. 2014, 42, 865-878. [CrossRef] [PubMed]

22. Gandhi, D.; Sivanesan, S.; Kannan, K. Manganese-Induced Neurotoxicity and Alterations in Gene Expression in Human Neuroblastoma SH-SY5Y Cells. Biol. Trace Elem. Res. 2018, 183, 245-253. [CrossRef] [PubMed]

23. Venkataramani, V.; Doeppner, T.R.; Willkommen, D.; Cahill, C.M.; Xin, Y.; Ye, G.; Liu, Y.; Southon, A.; Aron, A.; Au-Yeung, H.Y.; et al. Manganese causes neurotoxic iron accumulation via translational repression of amyloid precursor protein and H-Ferritin. J. Neurochem. 2018, 147, 831-848. [CrossRef]

24. Dieter, H.H.; Bayer, T.A.; Multhaup, G. Environmental copper and manganese in the pathophysiology of neurologic diseases (Alzheimer's disease and manganism). Acta Hydroch. Hydrob. 2005, 33, 72-78. [CrossRef]

25. Du, K.; Liu, M.; Pan, Y.; Zhong, X.; Wei, M. Association of Serum Manganese Levels with Alzheimer's Disease and Mild Cognitive Impairment: A Systematic Review and Meta-Analysis. Nutrients 2017, 9, 231. [CrossRef] [PubMed]

26. Perl, D.P.; Olanow, C.W. The neuropathology of manganese-induced Parkinsonism. J. Neuropathol. Exp. Neurol. 2007, 66, 675-682. [CrossRef] [PubMed]

27. Burton, N.C.; Schneider, J.S.; Syversen, T.; Guilarte, T.R. Effects of chronic manganese exposure on glutamatergic and GABAergic neurotransmitter markers in the nonhuman primate brain. Toxicol. Sci. 2009, 111, 131-139. [CrossRef]

28. Bouabid, S.; Tinakoua, A.; Lakhdar-Ghazal, N.; Benazzouz, A. Manganese neurotoxicity: Behavioral disorders associated with dysfunctions in the basal ganglia and neurochemical transmission. J. Neurochem. 2016, 136, 677-691. [CrossRef]

29. Lao, Y.; Dion, L.A.; Gilbert, G.; Bouchard, M.F.; Rocha, G.; Wang, Y.; Lepore, N.; Saint-Amour, D. Mapping the basal ganglia alterations in children chronically exposed to manganese. Sci. Rep. 2017, 7, 41804. [CrossRef] 
30. Zhao, Y.; Zhao, B. Oxidative stress and the pathogenesis of Alzheimer's disease. Oxid. Med. Cell. Longev. 2013, 2013, 316523. [CrossRef]

31. Belanger, M.; Allaman, I.; Magistretti, P.J. Brain energy metabolism: Focus on astrocyte-neuron metabolic cooperation. Cell Metab. 2011, 14, 724-738. [CrossRef] [PubMed]

32. Cobley, J.N.; Fiorello, M.L.; Bailey, D.M. 13 reasons why the brain is susceptible to oxidative stress. Redox Biol. 2018, 15, 490-503. [CrossRef] [PubMed]

33. Chtourou, Y.; Trabelsi, K.; Fetoui, H.; Mkannez, G.; Kallel, H.; Zeghal, N. Manganese induces oxidative stress, redox state unbalance and disrupts membrane bound ATPases on murine neuroblastoma cells in vitro: Protective role of silymarin. Neurochem. Res. 2011, 36, 1546-1557. [CrossRef] [PubMed]

34. Omar, R.A.; Chyan, Y.J.; Andorn, A.C.; Poeggeler, B.; Robakis, N.K.; Pappolla, M.A. Increased Expression but Reduced Activity of Antioxidant Enzymes in Alzheimer's Disease. J. Alzheimers Dis. 1999, 1, 139-145. [CrossRef]

35. Spranger, M.; Schwab, S.; Desiderato, S.; Bonmann, E.; Krieger, D.; Fandrey, J. Manganese augments nitric oxide synthesis in murine astrocytes: A new pathogenetic mechanism in manganism? Exp. Neurol. 1998, 149, 277-283. [CrossRef]

36. Tjalkens, R.B.; Popichak, K.A.; Kirkley, K.A. Inflammatory Activation of Microglia and Astrocytes in Manganese Neurotoxicity. Adv. Neurobiol. 2017, 18, 159-181. [CrossRef]

37. Kirkley, K.S.; Popichak, K.A.; Afzali, M.F.; Legare, M.E.; Tjalkens, R.B. Microglia amplify inflammatory activation of astrocytes in manganese neurotoxicity. J. Neuroinflammation 2017, 14, 99. [CrossRef]

38. Li, S.J.; Qin, W.X.; Peng, D.J.; Yuan, Z.X.; He, S.N.; Luo, Y.N.; Aschner, M.; Jiang, Y.M.; Liang, D.Y.; Xie, B.Y.; et al. Sodium P-aminosalicylic acid inhibits sub-chronic manganese-induced neuroinflammation in rats by modulating MAPK and COX-2. Neurotoxicology 2018, 64, 219-229. [CrossRef]

39. Popichak, K.A.; Afzali, M.F.; Kirkley, K.S.; Tjalkens, R.B. Glial-neuronal signaling mechanisms underlying the neuroinflammatory effects of manganese. J. Neuroinflammation 2018, 15, 324. [CrossRef]

40. Moreno, J.A.; Sullivan, K.A.; Carbone, D.L.; Hanneman, W.H.; Tjalkens, R.B. Manganese potentiates nuclear factor-kappaB-dependent expression of nitric oxide synthase 2 in astrocytes by activating soluble guanylate cyclase and extracellular responsive kinase signaling pathways. J. Neurosci. Res. 2008, 86, 2028-2038. [CrossRef]

41. Uttara, B.; Singh, A.V.; Zamboni, P.; Mahajan, R.T. Oxidative stress and neurodegenerative diseases: A review of upstream and downstream antioxidant therapeutic options. Curr. Neuropharmacol. 2009, 7, 65-74. [CrossRef] [PubMed]

42. Balmus, I.M.; Strungaru, S.A.; Ciobica, A.; Nicoara, M.N.; Dobrin, R.; Plavan, G.; Stefanescu, C. Preliminary Data on the Interaction between Some Biometals and Oxidative Stress Status in Mild Cognitive Impairment and Alzheimer's Disease Patients. Oxid. Med. Cell. Longev. 2017, 2017, 7156928. [CrossRef] [PubMed]

43. Mohandas, G.; Rao, S.V.; Rajini, P.S. Whey protein isolate enrichment attenuates manganese-induced oxidative stress and neurotoxicity in Drosophila melanogaster: Relevance to Parkinson's disease. Biomed. Pharmacother. 2017, 95, 1596-1606. [CrossRef] [PubMed]

44. Kwik-Uribe, C.; Smith, D.R. Temporal responses in the disruption of iron regulation by manganese. J. Neurosci. Res. 2006, 83, 1601-1610. [CrossRef] [PubMed]

45. Kehrer, J.P. The Haber-Weiss reaction and mechanisms of toxicity. Toxicology 2000, 149, 43-50. [CrossRef]

46. Gaschler, M.M.; Stockwell, B.R. Lipid peroxidation in cell death. Biochem. Biophys. Res.Commun. 2017, 482, 419-425. [CrossRef]

47. Ammal Kaidery, N.; Thomas, B. Current perspective of mitochondrial biology in Parkinson's disease. Neurochem. Int. 2018, 117, 91-113. [CrossRef] [PubMed]

48. Helley, M.P.; Pinnell, J.; Sportelli, C.; Tieu, K. Mitochondria: A Common Target for Genetic Mutations and Environmental Toxicants in Parkinson's Disease. Front. Genet. 2017, 8, 177. [CrossRef]

49. Milatovic, D.; Yin, Z.; Gupta, R.C.; Sidoryk, M.; Albrecht, J.; Aschner, J.L.; Aschner, M. Manganese induces oxidative impairment in cultured rat astrocytes. Toxicol. Sci. 2007, 98, 198-205. [CrossRef]

50. Zhang, F.; Xu, Z.; Gao, J.; Xu, B.; Deng, Y. In vitro effect of manganese chloride exposure on energy metabolism and oxidative damage of mitochondria isolated from rat brain. Environ. Toxicol. Pharmacol. 2008, 26, 232-236. [CrossRef]

51. Ijomone, O.M.; Aluko, O.M.; Okoh, C.O.A.; Martins, A.C., Jr.; Aschner, M. Role for calcium signaling in manganese neurotoxicity. J. Trace Elem. Med. Biol. 2019, 56, 146-155. [CrossRef] [PubMed] 
52. Gavin, C.E.; Gunter, K.K.; Gunter, T.E. Manganese and calcium transport in mitochondria: Implications for manganese toxicity. Neurotoxicology 1999, 20, 445-453. [PubMed]

53. Farina, M.; Avila, D.S.; da Rocha, J.B.; Aschner, M. Metals, oxidative stress and neurodegeneration: A focus on iron, manganese and mercury. Neurochem. Int. 2013, 62, 575-594. [CrossRef] [PubMed]

54. Martinez-Finley, E.J.; Gavin, C.E.; Aschner, M.; Gunter, T.E. Manganese neurotoxicity and the role of reactive oxygen species. Free Radic Biol. Med. 2013, 62, 65-75. [CrossRef] [PubMed]

55. Gavin, C.E.; Gunter, K.K.; Gunter, T.E. $\mathrm{Mn}^{2+}$ sequestration by mitochondria and inhibition of oxidative phosphorylation. Toxicol. Appl. Pharmacol. 1992, 115, 1-5. [CrossRef]

56. Gunter, T.E.; Gerstner, B.; Lester, T.; Wojtovich, A.P.; Malecki, J.; Swarts, S.G.; Brookes, P.S.; Gavin, C.E.; Gunter, K.K. An analysis of the effects of Mn2+ on oxidative phosphorylation in liver, brain, and heart mitochondria using state 3 oxidation rate assays. Toxicol. Appl. Pharmacol. 2010, 249, 65-75. [CrossRef] [PubMed]

57. Bonke, E.; Zwicker, K.; Drose, S. Manganese ions induce $\mathrm{H}_{2} \mathrm{O}_{2}$ generation at the ubiquinone binding site of mitochondrial complex II. Arch. Biochem. Biophys. 2015, 580, 75-83. [CrossRef]

58. Liu, Y.; Barber, D.S.; Zhang, P.; Liu, B. Complex II of the mitochondrial respiratory chain is the key mediator of divalent manganese-induced hydrogen peroxide production in microglia. Toxicol. Sci. 2013, 132, 298-306. [CrossRef]

59. Heron, P.; Cousins, K.; Boyd, C.; Daya, S. Paradoxical effects of copper and manganese on brain mitochondrial function. Life Sci. 2001, 68, 1575-1583. [CrossRef]

60. Neely, M.D.; Davison, C.A.; Aschner, M.; Bowman, A.B. From the Cover: Manganese and Rotenone-Induced Oxidative Stress Signatures Differ in iPSC-Derived Human Dopamine Neurons. Toxicol. Sci. 2017, 159, 366-379. [CrossRef]

61. Hardy, J.; Selkoe, D.J. The amyloid hypothesis of Alzheimer's disease: Progress and problems on the road to therapeutics. Science 2002, 297, 353-356. [CrossRef]

62. Lane, C.A.; Hardy, J.; Schott, J.M. Alzheimer's disease. Eur. J. Neurol. 2018, 25, 59-70. [CrossRef] [PubMed]

63. Querfurth, H.W.; LaFerla, F.M. Alzheimer's disease. N. Engl. J. Med. 2010, 362, 329-344. [CrossRef] [PubMed]

64. Wallin, C.; Kulkarni, Y.S.; Abelein, A.; Jarvet, J.; Liao, Q.; Strodel, B.; Olsson, L.; Luo, J.; Abrahams, J.P.; Sholts, S.B.; et al. Characterization of Mn(II) ion binding to the amyloid-beta peptide in Alzheimer's disease. J. Trace Elem. Med. Biol. 2016, 38, 183-193. [CrossRef] [PubMed]

65. Tougu, V.; Tiiman, A.; Palumaa, P. Interactions of $\mathrm{Zn}(\mathrm{II})$ and $\mathrm{Cu}(\mathrm{II})$ ions with Alzheimer's amyloid-beta peptide. Metal ion binding, contribution to fibrillization and toxicity. Metallomics 2011, 3, 250-261. [CrossRef] [PubMed]

66. Hane, F.; Leonenko, Z. Effect of metals on kinetic pathways of amyloid-beta aggregation. Biomolecules 2014, 4, 101-116. [CrossRef] [PubMed]

67. Jarvet, J.; Danielsson, J.; Damberg, P.; Oleszczuk, M.; Graslund, A. Positioning of the Alzheimer Abeta(1-40) peptide in SDS micelles using NMR and paramagnetic probes. J. Biomol. NMR 2007, 39, 63-72. [CrossRef]

68. Molina, J.A.; Jimenez-Jimenez, F.J.; Aguilar, M.V.; Meseguer, I.; Mateos-Vega, C.J.; Gonzalez-Munoz, M.J.; de Bustos, F.; Porta, J.; Orti-Pareja, M.; Zurdo, M.; et al. Cerebrospinal fluid levels of transition metals in patients with Alzheimer's disease. J. Neural Transm. 1998, 105, 479-488. [CrossRef]

69. Gonzalez-Dominguez, R.; Garcia-Barrera, T.; Gomez-Ariza, J.L. Homeostasis of metals in the progression of Alzheimer's disease. Biometals 2014, 27, 539-549. [CrossRef]

70. Hare, D.J.; Faux, N.G.; Roberts, B.R.; Volitakis, I.; Martins, R.N.; Bush, A.I. Lead and manganese levels in serum and erythrocytes in Alzheimer's disease and mild cognitive impairment: Results from the Australian Imaging, Biomarkers and Lifestyle Flagship Study of Ageing. Metallomics 2016, 8, 628-632. [CrossRef]

71. Calderon-Garciduenas, L.; Franco-Lira, M.; Mora-Tiscareno, A.; Medina-Cortina, H.; Torres-Jardon, R.; Kavanaugh, M. Early Alzheimer's and Parkinson's disease pathology in urban children: Friend versus Foe responses-It is time to face the evidence. Biomed. Res. Int. 2013, 2013, 161687. [CrossRef] [PubMed]

72. Calderon-Garciduenas, L.; D’Angiulli, A.; Kulesza, R.J.; Torres-Jardon, R.; Osnaya, N.; Romero, L.; Keefe, S.; Herritt, L.; Brooks, D.M.; Avila-Ramirez, J.; et al. Air pollution is associated with brainstem auditory nuclei pathology and delayed brainstem auditory evoked potentials. Int. J. Dev. Neurosci. 2011, 29, 365-375. [CrossRef] [PubMed] 
73. Calderon-Garciduenas, L.; Azzarelli, B.; Acuna, H.; Garcia, R.; Gambling, T.M.; Osnaya, N.; Monroy, S.; MR, D.E.L.T.; Carson, J.L.; Villarreal-Calderon, A.; et al. Air pollution and brain damage. Toxicol. Pathol. 2002, 30, 373-389. [CrossRef] [PubMed]

74. Calderon-Garciduenas, L.; Maronpot, R.R.; Torres-Jardon, R.; Henriquez-Roldan, C.; Schoonhoven, R.; Acuna-Ayala, H.; Villarreal-Calderon, A.; Nakamura, J.; Fernando, R.; Reed, W.; et al. DNA damage in nasal and brain tissues of canines exposed to air pollutants is associated with evidence of chronic brain inflammation and neurodegeneration. Toxicol. Pathol. 2003, 31, 524-538. [CrossRef] [PubMed]

75. Guilarte, T.R.; Burton, N.C.; Verina, T.; Prabhu, V.V.; Becker, K.G.; Syversen, T.; Schneider, J.S. Increased APLP1 expression and neurodegeneration in the frontal cortex of manganese-exposed non-human primates. J. Neurochem. 2008, 105, 1948-1959. [CrossRef] [PubMed]

76. Schneider, J.S.; Decamp, E.; Koser, A.J.; Fritz, S.; Gonczi, H.; Syversen, T.; Guilarte, T.R. Effects of chronic manganese exposure on cognitive and motor functioning in non-human primates. Brain Res. 2006, 1118, 222-231. [CrossRef] [PubMed]

77. Marcus, D.L.; Strafaci, J.A.; Freedman, M.L. Differential neuronal expression of manganese superoxide dismutase in Alzheimer's disease. Med. Sci. Monit. 2006, 12, BR8-BR14.

78. Benskey, M.J.; Perez, R.G.; Manfredsson, F.P. The contribution of alpha synuclein to neuronal survival and function-Implications for Parkinson's disease. J. Neurochem. 2016, 137, 331-359. [CrossRef]

79. Recasens, A.; Dehay, B. Alpha-synuclein spreading in Parkinson's disease. Front. Neuroanat. 2014, 8, 159. [CrossRef]

80. Carboni, E.; Lingor, P. Insights on the interaction of alpha-synuclein and metals in the pathophysiology of Parkinson's disease. Metallomics 2015, 7, 395-404. [CrossRef]

81. Peres, T.V.; Schettinger, M.R.; Chen, P.; Carvalho, F.; Avila, D.S.; Bowman, A.B.; Aschner, M. Manganese-induced neurotoxicity: A review of its behavioral consequences and neuroprotective strategies. BMC Pharmacol. Toxicol. 2016, 17, 57. [CrossRef] [PubMed]

82. Binolfi, A.; Rasia, R.M.; Bertoncini, C.W.; Ceolin, M.; Zweckstetter, M.; Griesinger, C.; Jovin, T.M.; Fernandez, C.O. Interaction of alpha-synuclein with divalent metal ions reveals key differences: A link between structure, binding specificity and fibrillation enhancement. J. Am. Chem. Soc. 2006, 128, 9893-9901. [CrossRef] [PubMed]

83. Xu, B.; Jin, C.H.; Deng, Y.; Liu, W.; Yang, T.Y.; Feng, S.; Xu, Z.F. Alpha-synuclein oligomerization in manganese-induced nerve cell injury in brain slices: A role of NO-mediated S-nitrosylation of protein disulfide isomerase. Mol. Neurobiol. 2014, 50, 1098-1110. [CrossRef] [PubMed]

84. Cai, T.; Yao, T.; Zheng, G.; Chen, Y.; Du, K.; Cao, Y.; Shen, X.; Chen, J.; Luo, W. Manganese induces the overexpression of alpha-synuclein in PC12 cells via ERK activation. Brain Res. 2010, 1359, 201-207. [CrossRef] [PubMed]

85. Harischandra, D.S.; Jin, H.; Anantharam, V.; Kanthasamy, A.; Kanthasamy, A.G. alpha-Synuclein protects against manganese neurotoxic insult during the early stages of exposure in a dopaminergic cell model of Parkinson's disease. Toxicol. Sci. 2015, 143, 454-468. [CrossRef] [PubMed]

86. Harischandra, D.S.; Ghaisas, S.; Rokad, D.; Zamanian, M.; Jin, H.; Anantharam, V.; Kimber, M.; Kanthasamy, A.; Kanthasamy, A.G. Environmental neurotoxicant manganese regulates exosome-mediated extracellular miRNAs in cell culture model of Parkinson's disease: Relevance to alpha-synuclein misfolding in metal neurotoxicity. Neurotoxicology 2018, 64, 267-277. [CrossRef] [PubMed]

87. Finnerty, J.R.; Wang, W.X.; Hebert, S.S.; Wilfred, B.R.; Mao, G.; Nelson, P.T. The miR-15/107 group of microRNA genes: Evolutionary biology, cellular functions, and roles in human diseases. J. Mol. Biol. 2010, 402, 491-509. [CrossRef] [PubMed]

88. Muller, M.; Kuiperij, H.B.; Claassen, J.A.; Kusters, B.; Verbeek, M.M. MicroRNAs in Alzheimer's disease: Differential expression in hippocampus and cell-free cerebrospinal fluid. Neurobiol. Aging 2014, 35, 152-158. [CrossRef]

89. Harischandra, D.S.; Rokad, D.; Neal, M.L.; Ghaisas, S.; Manne, S.; Sarkar, S.; Panicker, N.; Zenitsky, G.; Jin, H.J.; Lewis, M.; et al. Manganese promotes the aggregation and prion-like cell-to-cell exosomal transmission of alpha-synuclein. Sci. Signal. 2019, 12, eaau4543. [CrossRef]

90. Vijayan, B.; Raj, V.; Nandakumar, S.; Kishore, A.; Thekkuveettil, A. Spermine protects alpha-synuclein expressing dopaminergic neurons from manganese-induced degeneration. Cell Biol. Toxicol. 2019, 35, 147-159. [CrossRef] 
91. Yan, D.Y.; Liu, C.; Tan, X.; Ma, Z.; Wang, C.; Deng, Y.; Liu, W.; Xu, Z.F.; Xu, B. Mn-Induced Neurocytes Injury and Autophagy Dysfunction in Alpha-Synuclein Wild-Type and Knock-Out Mice: Highlighting the Role of Alpha-Synuclein. Neurotox. Res. 2019, 36, 66-80. [CrossRef] [PubMed]

92. Kinghorn, K.J.; Asghari, A.M.; Castillo-Quan, J.I. The emerging role of autophagic-lysosomal dysfunction in Gaucher disease and Parkinson's disease. Neural Regen. Res. 2017, 12, 380-384. [CrossRef] [PubMed]

93. Zhang, Z.; Miah, M.; Culbreth, M.; Aschner, M. Autophagy in Neurodegenerative Diseases and Metal Neurotoxicity. Neurochem. Res. 2016, 41, 409-422. [CrossRef] [PubMed]

94. Fine, A.; Hoyle, C.; Maclean, C.J.; Levatte, T.L.; Baker, H.F.; Ridley, R.M. Learning impairments following injection of a selective cholinergic immunotoxin, ME20.4 IgG-saporin, into the basal nucleus of Meynert in monkeys. Neuroscience 1997, 81, 331-343. [CrossRef]

95. Miranda, M.I.; Bermudez-Rattoni, F. Reversible inactivation of the nucleus basalis magnocellularis induces disruption of cortical acetylcholine release and acquisition, but not retrieval, of aversive memories. Proc. Natl. Acad. Sci. USA 1999, 96, 6478-6482. [CrossRef]

96. Ferreira-Vieira, T.H.; Guimaraes, I.M.; Silva, F.R.; Ribeiro, F.M. Alzheimer's disease: Targeting the Cholinergic System. Curr. Neuropharmacol. 2016, 14, 101-115. [CrossRef]

97. Minger, S.L.; Esiri, M.M.; McDonald, B.; Keene, J.; Carter, J.; Hope, T.; Francis, P.T. Cholinergic deficits contribute to behavioral disturbance in patients with dementia. Neurology 2000, 55, 1460-1467. [CrossRef]

98. Mesulam, M.M.; Lalehzari, N.; Rahmani, F.; Ohm, D.; Shahidehpour, R.; Kim, G.; Gefen, T.; Weintraub, S.; Bigio, E.; Geula, C. Cortical cholinergic denervation in primary progressive aphasia with Alzheimer pathology. Neurology 2019, 92, e1580-e1588. [CrossRef]

99. Whitehouse, P.J.; Price, D.L.; Struble, R.G.; Clark, A.W.; Coyle, J.T.; Delon, M.R. Alzheimer's disease and senile dementia: Loss of neurons in the basal forebrain. Science 1982, 215, 1237-1239. [CrossRef]

100. Chtourou, Y.; Fetoui, H.; Garoui, E.M.; Boudawara, T.; Zeghal, N. Improvement of cerebellum redox states and cholinergic functions contribute to the beneficial effects of silymarin against manganese-induced neurotoxicity. Neurochem. Res. 2012, 37, 469-479. [CrossRef]

101. Fernsebner, K.; Zorn, J.; Kanawati, B.; Walker, A.; Michalke, B. Manganese leads to an increase in markers of oxidative stress as well as to a shift in the ratio of Fe(II)/(III) in rat brain tissue. Metallomics 2014, 6, 921-931. [CrossRef]

102. Liapi, C.; Zarros, A.; Galanopoulou, P.; Theocharis, S.; Skandali, N.; Al-Humadi, H.; Anifantaki, F.; Gkrouzman, E.; Mellios, Z.; Tsakiris, S. Effects of short-term exposure to manganese on the adult rat brain antioxidant status and the activities of acetylcholinesterase, $(\mathrm{Na}, \mathrm{K})$-ATPase and $\mathrm{Mg}$-ATPase: Modulation by L-cysteine. Basic Clin. Pharmacol. Toxicol. 2008, 103, 171-175. [CrossRef]

103. Lai, J.C.; Leung, T.K.; Lim, L. Brain regional distribution of glutamic acid decarboxylase, choline acetyltransferase, and acetylcholinesterase in the rat: Effects of chronic manganese chloride administration after two years. J. Neurochem. 1981, 36, 1443-1448. [CrossRef]

104. Lai, J.C.; Leung, T.K.; Lim, L. The ontogeny of acetylcholinesterase activities in rat brain regions and the effect of chronic treatment with manganese chloride. J. Neurochem. 1982, 39, 1767-1769. [CrossRef] [PubMed]

105. Finkelstein, Y.; Milatovic, D.; Aschner, M. Modulation of cholinergic systems by manganese. Neurotoxicology 2007, 28, 1003-1014. [CrossRef] [PubMed]

106. Milatovic, D.; Zaja-Milatovic, S.; Gupta, R.C.; Yu, Y.; Aschner, M. Oxidative damage and neurodegeneration in manganese-induced neurotoxicity. Toxicol. Appl. Pharmacol. 2009, 240, 219-225. [CrossRef] [PubMed]

107. Santos, D.; Milatovic, D.; Andrade, V.; Batoreu, M.C.; Aschner, M.; Marreilha dos Santos, A.P. The inhibitory effect of manganese on acetylcholinesterase activity enhances oxidative stress and neuroinflammation in the rat brain. Toxicology 2012, 292, 90-98. [CrossRef]

108. Ye, Q.; Kim, J. Loss of hfe function reverses impaired recognition memory caused by olfactory manganese exposure in mice. Toxicol. Res. 2015, 31, 17-23. [CrossRef]

109. Schetinger, M.R.C.; Peres, T.V.; Arantes, L.P.; Carvalho, F.; Dressler, V.; Heidrich, G.; Bowman, A.B.; Aschner, M. Combined exposure to methylmercury and manganese during L1 larval stage causes motor dysfunction, cholinergic and monoaminergic up-regulation and oxidative stress in L4 Caenorhabditis elegans. Toxicology 2019, 411, 154-162. [CrossRef]

110. Melo, J.B.; Agostinho, P.; Oliveira, C.R. Involvement of oxidative stress in the enhancement of acetylcholinesterase activity induced by amyloid beta-peptide. Neurosci. Res. 2003, 45, 117-127. [CrossRef] 
111. Inestrosa, N.C.; Alvarez, A.; Perez, C.A.; Moreno, R.D.; Vicente, M.; Linker, C.; Casanueva, O.I.; Soto, C.; Garrido, J. Acetylcholinesterase accelerates assembly of amyloid-beta-peptides into Alzheimer's fibrils: Possible role of the peripheral site of the enzyme. Neuron 1996, 16, 881-891. [CrossRef]

112. Salazar, J.; Mena, N.; Hunot, S.; Prigent, A.; Alvarez-Fischer, D.; Arredondo, M.; Duyckaerts, C.; Sazdovitch, V.; Zhao, L.; Garrick, L.M.; et al. Divalent metal transporter 1 (DMT1) contributes to neurodegeneration in animal models of Parkinson's disease. Proc. Natl. Acad. Sci. USA 2008, 105, 18578-18583. [CrossRef]

113. Huang, E.; Ong, W.Y.; Connor, J.R. Distribution of divalent metal transporter-1 in the monkey basal ganglia. Neuroscience 2004, 128, 487-496. [CrossRef] [PubMed]

114. Wolff, N.A.; Garrick, M.D.; Zhao, L.; Garrick, L.M.; Ghio, A.J.; Thevenod, F. A role for divalent metal transporter (DMT1) in mitochondrial uptake of iron and manganese. Sci. Rep. 2018, 8, 211. [CrossRef] [PubMed]

115. Sanchez-Betancourt, J.; Anaya-Martinez, V.; Gutierrez-Valdez, A.L.; Ordonez-Librado, J.L.; Montiel-Flores, E.; Espinosa-Villanueva, J.; Reynoso-Erazo, L.; Avila-Costa, M.R. Manganese mixture inhalation is a reliable Parkinson disease model in rats. Neurotoxicology 2012, 33, 1346-1355. [CrossRef] [PubMed]

116. Khalid, M.; Aoun, R.A.; Mathews, T.A. Altered striatal dopamine release following a sub-acute exposure to manganese. J. Neurosci. Methods 2011, 202, 182-191. [CrossRef] [PubMed]

117. Benedetto, A.; Au, C.; Aschner, M. Manganese-induced dopaminergic neurodegeneration: Insights into mechanisms and genetics shared with Parkinson's disease. Chem. Rev. 2009, 109, 4862-4884. [CrossRef]

118. Guilarte, T.R.; Burton, N.C.; McGlothan, J.L.; Verina, T.; Zhou, Y.; Alexander, M.; Pham, L.; Griswold, M.; Wong, D.F.; Syversen, T.; et al. Impairment of nigrostriatal dopamine neurotransmission by manganese is mediated by pre-synaptic mechanism(s): Implications to manganese-induced parkinsonism. J. Neurochem. 2008, 107, 1236-1247. [CrossRef]

119. Lee, E.Y.; Flynn, M.R.; Lewis, M.M.; Mailman, R.B.; Huang, X. Welding-related brain and functional changes in welders with chronic and low-level exposure. Neurotoxicology 2018, 64, 50-59. [CrossRef]

120. Pavese, N.; Brooks, D.J. Imaging neurodegeneration in Parkinson's disease. Biochim. Biophys. Acta 2009, 1792, 722-729. [CrossRef]

121. Stoessl, A.J. Neuroimaging in Parkinson's disease: From pathology to diagnosis. Parkinsonism Relat. Disord. 2012, 18, S55-S59. [CrossRef]

122. Baek, S.Y.; Kim, Y.H.; Oh, S.O.; Lee, C.R.; Yoo, C.I.; Lee, J.H.; Lee, H.; Sim, C.S.; Park, J.; Kim, J.W.; et al. Manganese does not alter the severe neurotoxicity of MPTP. Hum. Exp. Toxicol. 2007, 26, 203-211. [CrossRef] [PubMed]

123. Guilarte, T.R.; Yeh, C.L.; McGlothan, J.L.; Perez, J.; Finley, P.; Zhou, Y.; Wong, D.F.; Dydak, U.; Schneider, J.S. PET imaging of dopamine release in the frontal cortex of manganese-exposed non-human primates. $J$. Neurochem. 2019. [CrossRef] [PubMed]

124. Criswell, S.R.; Warden, M.N.; Searles Nielsen, S.; Perlmutter, J.S.; Moerlein, S.M.; Sheppard, L.; Lenox-Krug, J.; Checkoway, H.; Racette, B.A. Selective D2 receptor PET in manganese-exposed workers. Neurology 2018, 91, e1022-e1030. [CrossRef] [PubMed]

125. Nikolaus, S.; Antke, C.; Muller, H.W. In vivo imaging of synaptic function in the central nervous system: I. Movement disorders and dementia. Behav. Brain Res. 2009, 204, 1-31. [CrossRef] [PubMed]

126. Antonini, A.; Schwarz, J.; Oertel, W.H.; Pogarell, O.; Leenders, K.L. Long-term changes of striatal dopamine $\mathrm{D}_{2}$ receptors in patients with Parkinson's disease: A study with positron emission tomography and [11C]raclopride. Mov. Disord. 1997, 12, 33-38. [CrossRef]

127. Antonini, A.; Vontobel, P.; Psylla, M.; Gunther, I.; Maguire, P.R.; Missimer, J.; Leenders, K.L. Complementary positron emission tomographic studies of the striatal dopaminergic system in Parkinson's disease. Arch. Neurol. 1995, 52, 1183-1190. [CrossRef]

128. Higashi, Y.; Asanuma, M.; Miyazaki, I.; Hattori, N.; Mizuno, Y.; Ogawa, N. Parkin attenuates manganese-induced dopaminergic cell death. J. Neurochem. 2004, 89, 1490-1497. [CrossRef]

129. Carmona, A.; Roudeau, S.; Perrin, L.; Veronesi, G.; Ortega, R. Environmental manganese compounds accumulate as $\mathrm{Mn}(\mathrm{II})$ within the Golgi apparatus of dopamine cells: Relationship between speciation, subcellular distribution, and cytotoxicity. Metallomics 2014, 6, 822-832. [CrossRef]

130. Ducic, T.; Barski, E.; Salome, M.; Koch, J.C.; Bahr, M.; Lingor, P. X-ray fluorescence analysis of iron and manganese distribution in primary dopaminergic neurons. J. Neurochem. 2013, 124, 250-261. [CrossRef] 
131. Latchoumycandane, C.; Anantharam, V.; Kitazawa, M.; Yang, Y.; Kanthasamy, A.; Kanthasamy, A.G. Protein kinase Cdelta is a key downstream mediator of manganese-induced apoptosis in dopaminergic neuronal cells. J. Pharmacol. Exp. Ther. 2005, 313, 46-55. [CrossRef] [PubMed]

132. Anantharam, V.; Kitazawa, M.; Latchoumycandane, C.; Kanthasamy, A.; Kanthasamy, A.G. Blockade of PKCdelta proteolytic activation by loss of function mutants rescues mesencephalic dopaminergic neurons from methylcyclopentadienyl manganese tricarbonyl (MMT)-induced apoptotic cell death. Ann. N. Y. Acad. Sci. 2004, 1035, 271-289. [CrossRef] [PubMed]

133. Wan, C.; Ma, X.; Shi, S.; Zhao, J.; Nie, X.; Han, J.; Xiao, J.; Wang, X.; Jiang, S.; Jiang, J. Pivotal roles of p53 transcription-dependent and -independent pathways in manganese-induced mitochondrial dysfunction and neuronal apoptosis. Toxicol. Appl. Pharmacol. 2014, 281, 294-302. [CrossRef] [PubMed]

134. Huttinger-Kirchhof, N.; Cam, H.; Griesmann, H.; Hofmann, L.; Beitzinger, M.; Stiewe, T. The p53 family inhibitor DeltaNp73 interferes with multiple developmental programs. Cell Death Differ. 2006, 13, 174-177. [CrossRef] [PubMed]

135. Kim, D.S.; Jin, H.; Anantharam, V.; Gordon, R.; Kanthasamy, A.; Kanthasamy, A.G. p73 gene in dopaminergic neurons is highly susceptible to manganese neurotoxicity. Neurotoxicology 2017, 59, 231-239. [CrossRef] [PubMed]

136. Mijatovic, J.; Airavaara, M.; Planken, A.; Auvinen, P.; Raasmaja, A.; Piepponen, T.P.; Costantini, F.; Ahtee, L.; Saarma, M. Constitutive Ret activity in knock-in multiple endocrine neoplasia type B mice induces profound elevation of brain dopamine concentration via enhanced synthesis and increases the number of TH-positive cells in the substantia nigra. J. Neurosci. 2007, 27, 4799-4809. [CrossRef] [PubMed]

137. Hurley, M.J.; Mash, D.C.; Jenner, P. Markers for dopaminergic neurotransmission in the cerebellum in normal individuals and patients with Parkinson's disease examined by RT-PCR. Eur. J. Neurosci. 2003, 18, 2668-2672. [CrossRef]

138. Ma, R.E.; Ward, E.J.; Yeh, C.L.; Snyder, S.; Long, Z.; Gokalp Yavuz, F.; Zauber, S.E.; Dydak, U. Thalamic GABA levels and occupational manganese neurotoxicity: Association with exposure levels and brain MRI. Neurotoxicology 2018, 64, 30-42. [CrossRef]

139. Racette, B.A.; Criswell, S.R.; Lundin, J.I.; Hobson, A.; Seixas, N.; Kotzbauer, P.T.; Evanoff, B.A.; Perlmutter, J.S.; Zhang, J.; Sheppard, L.; et al. Increased risk of parkinsonism associated with welding exposure. Neurotoxicology 2012, 33, 1356-1361. [CrossRef]

140. Bowman, A.B.; Aschner, M. Considerations on manganese (Mn) treatments for in vitro studies. Neurotoxicology 2014, 41, 141-142. [CrossRef]

141. Graybiel, A.M. The basal ganglia. Curr. Biol. 2000, 10, R509-R511. [CrossRef]

142. Tuschl, K.; Mills, P.B.; Clayton, P.T. Manganese and the brain. Int. Rev. Neurobiol. 2013, 110, $277-312$. [CrossRef] [PubMed]

143. Struve, M.F.; McManus, B.E.; Wong, B.A.; Dorman, D.C. Basal ganglia neurotransmitter concentrations in rhesus monkeys following subchronic manganese sulfate inhalation. Am. J. Ind. Med. 2007, 50, 772-778. [CrossRef] [PubMed]

144. Dydak, U.; Jiang, Y.M.; Long, L.L.; Zhu, H.; Chen, J.; Li, W.M.; Edden, R.A.; Hu, S.; Fu, X.; Long, Z.; et al. In vivo measurement of brain GABA concentrations by magnetic resonance spectroscopy in smelters occupationally exposed to manganese. Environ. Health Perspect. 2011, 119, 219-224. [CrossRef] [PubMed]

145. Long, Z.; Li, X.R.; Xu, J.; Edden, R.A.; Qin, W.P.; Long, L.L.; Murdoch, J.B.; Zheng, W.; Jiang, Y.M.; Dydak, U. Thalamic GABA predicts fine motor performance in manganese-exposed smelter workers. PLoS ONE 2014, 9, e88220. [CrossRef] [PubMed]

146. Dharmadhikari, S.; Ma, R.; Yeh, C.L.; Stock, A.K.; Snyder, S.; Zauber, S.E.; Dydak, U.; Beste, C. Striatal and thalamic GABA level concentrations play differential roles for the modulation of response selection processes by proprioceptive information. Neuroimage 2015, 120, 36-42. [CrossRef] [PubMed]

147. Emir, U.E.; Tuite, P.J.; Oz, G. Elevated pontine and putamenal GABA levels in mild-moderate Parkinson disease detected by 7 tesla proton MRS. PLoS ONE 2012, 7, e30918. [CrossRef]

148. Casjens, S.; Dydak, U.; Dharmadhikari, S.; Lotz, A.; Lehnert, M.; Quetscher, C.; Stewig, C.; Glaubitz, B.; Schmidt-Wilcke, T.; Edmondson, D.; et al. Association of exposure to manganese and iron with striatal and thalamic GABA and other neurometabolites-Neuroimaging results from the WELDOX II study. Neurotoxicology 2018, 64, 60-67. [CrossRef] 
149. Koller, W.C.; Lyons, K.E.; Truly, W. Effect of levodopa treatment for parkinsonism in welders: A double-blind study. Neurology 2004, 62, 730-733. [CrossRef]

150. Sadek, A.H.; Rauch, R.; Schulz, P.E. Parkinsonism due to manganism in a welder. Int. J. Toxicol. 2003, 22, 393-401. [CrossRef]

151. Ommati, M.M.; Heidari, R.; Ghanbarinejad, V.; Abdoli, N.; Niknahad, H. Taurine Treatment Provides Neuroprotection in a Mouse Model of Manganism. Biol. Trace Elem. Res. 2018. [CrossRef] [PubMed]

152. Ahmadi, N.; Ghanbarinejad, V.; Ommati, M.M.; Jamshidzadeh, A.; Heidari, R. Taurine prevents mitochondrial membrane permeabilization and swelling upon interaction with manganese: Implication in the treatment of cirrhosis-associated central nervous system complications. J. Biochem. Mol. Toxicol. 2018, 32, e22216. [CrossRef] [PubMed]

153. Fordahl, S.C.; Anderson, J.G.; Cooney, P.T.; Weaver, T.L.; Colyer, C.L.; Erikson, K.M. Manganese exposure inhibits the clearance of extracellular GABA and influences taurine homeostasis in the striatum of developing rats. Neurotoxicology 2010, 31, 639-646. [CrossRef] [PubMed]

154. Lu, C.L.; Tang, S.; Meng, Z.J.; He, Y.Y.; Song, L.Y.; Liu, Y.P.; Ma, N.; Li, X.Y.; Guo, S.C. Taurine improves the spatial learning and memory ability impaired by sub-chronic manganese exposure. J. Biomed. Sci. 2014, 21, 51. [CrossRef]

155. Ling, J.; Yang, S.; Huang, Y.; Wei, D.; Cheng, W. Identifying key genes, pathways and screening therapeutic agents for manganese-induced Alzheimer disease using bioinformatics analysis. Medicine 2018, 97, e10775. [CrossRef]

156. Wang, B.J.; Her, G.M.; Hu, M.K.; Chen, Y.W.; Tung, Y.T.; Wu, P.Y.; Hsu, W.M.; Lee, H.; Jin, L.W.; Hwang, S.L.; et al. ErbB2 regulates autophagic flux to modulate the proteostasis of APP-CTFs in Alzheimer's disease. Proc. Natl. Acad. Sci. USA 2017, 114, E3129-E3138. [CrossRef]

(C) 2019 by the authors. Licensee MDPI, Basel, Switzerland. This article is an open access article distributed under the terms and conditions of the Creative Commons Attribution (CC BY) license (http://creativecommons.org/licenses/by/4.0/). 